\title{
The Union of Hearts Depicted: Gladstone, Home Rule and United Ireland
}

\author{
D. W. Bebbington \\ Professor of History, University of Stirling
}

William Ewart Gladstone detested political cartoons. They embodied caricature, the exaggeration of a particular feature into a deformity to excite ridicule or hatred. Cartoons, Gladstone once pointed out, had not existed in ancient Greece. There the ideal of human beauty was so deeply cherished that its distortion was not tolerated. ${ }^{1}$ Yet cartoons did the statesman powerful service during his long career. Their very frequency consolidated his image as a popular politician, bringing out qualities such as courage and tenacity that he was happy to have publicised. Nowhere, however, did they advance his cause more than in Ireland after the introduction of Home Rule. The nationalist journal United Ireland, as the illustrations in this paper will show, gave currency to striking depictions of Gladstone; and they vividly portrayed the union of hearts between England and Ireland that he preached so persistently in the late $1880 \mathrm{~s}$. The purpose of this article is to examine a sample of the cartoons, but first they need to be placed in their context.

The great age of British political cartoons is usually located in the late eighteenth and early nineteenth centuries, the era of James Gillray and George Cruickshank. By the beginnings of Gladstone's career in the 1830 s and 1840 s, the single sheets of the earlier period were being replaced by comic journals of which the most celebrated was Punch. Ireland was less well served, for it was not until 1870 that the first comic journal was launched in Dublin. Soon, however, the cartoon became a popular genre produced by able artists. John F. O'Hea (1850-1922) 
contributed telling cartoons to the press from the late 1860s down to the decade of the Irish revolution, ${ }^{2}$ and Thomas Fitzpatrick (1860-1912), who began his career as an illustrator in the early 1880 s, was eventually to found his own satirical magazine, The Lepracaun, in $1905 .^{3}$ The prints that we shall examine fall into this age of the burgeoning of the cartoon in Ireland. It was not the case that the Irish people needed visual means of communication to compensate for their illiteracy. By $189182 \%$ of the Irish population could sign the marriage register and a higher proportion could read. ${ }^{4}$ Nevertheless cartoons exerted a potent appeal. Images were drawn from a variety of fields familiar to the mass of the people: folklore, entertainment, military conflict, the law, the Bible and popular art. The resulting illustrations probably did less to transmit new political ideas and allegiances than to reflect back existing convictions and prejudices, so reinforcing rather than creating attitudes. Yet they did help identify the friends and foes of the cause to which their constituency was already committed. To that extent they could be agents of change, dignifying supporters and demonising opponents. The cartoons could go beyond revealing assumptions about the affairs of the day to playing a role in the construction and destruction of popular perceptions of politicians.

The journal from which the pictures are taken, United Ireland, was a weekly, published each Saturday. Its predecessor, The Irishman, had begun in 1858. From 1865 to 1881 this newspaper was owned by Richard Pigott, later the notorious forger in the 'Parnellism and Crime' affair. Under his guidance its editorial stance was critical of the involvement of politicians in the Land War. In 1881, however, Charles Stewart Parnell's nationalist party bought the newspaper, merged it with the Flag of Ireland and created United Ireland. ${ }^{5}$ Now it gave full coverage to the Land League, 
Parnell's organisation for sustaining the agitation against landlordism. The paper carried no advertisements at all so that it could concentrate instead on publishing nationalist news, managing to achieve high sales through the popularity of its editorial statements and its coloured cartoons. ${ }^{6}$ Its circulation, which in 1882 was 30,000, had reached 100,000 by $1886 .^{7}$ The editor claimed in retrospect that it was regularly seen by half a million readers. ${ }^{8}$ The newspaper's significance can be appreciated by contrasting the figures for the circulation of political prints in the British golden age. In Gilray's day, because of technical limitations, in most years the total production of political prints was no more than 50,000. The most widely distributed of all the satirical sheets, Cruickshanks's illustrations to George Hone's booklet, The Political House that Jack Built (1819-20), sold only about 100,000 copies. ${ }^{9}$ In only a single instance, therefore, was the regular weekly circulation of United Ireland equalled by the total sales of a political print in the pre-Reform era. The cartoons reached a vast audience.

The editor, chosen by Parnell in 1881, was William O'Brien, and he remained in the newspaper's chair throughout the 1880s. O'Brien had previously shown journalistic flair on the Freeman's Journal, the organ of the nationalist parliamentary party. In the pages of United Ireland, however, he dwelt not on constitutional politics but on the agrarian issues that concerned the Irish masses, concentrating his fire on landlordism. ${ }^{10}$ The degree to which O'Brien was exclusively concerned with the Land War can be exaggerated. Philip Bull has argued that he supported tenant farmers as part of a broader nationalist commitment. ${ }^{11}$ Certainly in the year after his appointment as editor he was prepared to enter the House of Commons as MP for his home town of Mallow, Co. Cork. In parliament and in the pages of United Ireland he 
was loyally uncritical of Parnell. In 1881, for example, he followed his leader's policy over Gladstone's Land Act. Rather than either endorsing or rejecting the measure, he advocated testing it before the Land Courts in order to see whether it would benefit the people. This was a moderate and essentially pragmatic stance. Yet O'Brien's journalistic hallmark was to dress up an issue as though it were part of an apocalyptic struggle. In this case he launched into an inflammatory assault on landlordism. 'Impoverish it', he wrote, 'and manacle it in the Land Courts, if that be possible; and if not, or whether or not, hunt it down steadily, patiently, remorselessly - to the death!' ${ }^{12}$ The unbridled rhetoric was typical of O'Brien. It was part of a calculated strategy of drumming up support by sounding far more radical than in reality he was. He thought up extraordinary schemes to capture the popular imagination. In the following year, for instance, he advocated kidnapping the Lord Lieutenant and Chief Secretary and holding them hostage in the Dublin mountains until land reforms were conceded. ${ }^{13}$ O'Brien, who as a boy had enjoyed playing with toy soldiers, loved metaphors of battle. ${ }^{14}$ It is hardly surprising that in October 1881 he was arrested for 'treasonable and seditious writings' and that in February 1883 Dublin Castle put him on trial for questioning the course of justice. ${ }^{15}$ O'Brien returned the compliment by fierce assaults on the Irish administration, and especially virulent attacks on Lord Spencer, the Lord Lieutenant in the latter part of Gladstone's second ministry. When the government left office in June 1885, United Ireland rejoiced at the fall of Spencer, who 'had struck murderous blow after blow at the people under his rod'. ${ }^{16}$ The editor had been a strident critic of Gladstone's administration in Ireland. Before the statesman's declaration in favour of Home Rule, therefore, O'Brien was no friend to his policies. 
There was, however, another side to O'Brien. He does not seem to have developed a personal animus against Gladstone. In his autobiography of 1905, Recollections, he treats the statesman with respect. In writing of Gladstone's second administration, for example, O'Brien remarks that the Prime Minister 'hated Coercion'. ${ }^{17}$ Although O'Brien's attitude was coloured by Gladstone's later championship of Home Rule, there is something here of the reverence of a typical Liberal backbencher. In his later volume, Evening Memories (1920), O’Brien recalls Gladstone, when introducing the first Home Rule Bill in April 1886, as a 'massive figure set four-square to all the world's contumely in a great cause'. ${ }^{18}$ Like many another, O'Brien seems to have been bowled over by his experience of Gladstone's oratory. A man of warm passions, O'Brien had them kindled by Gladstone's newfound commitment to the Irish cause. The editor's esteem for the statesman showed in the pages of United Ireland from 1886 onwards. O'Brien guided the newspaper's policy and ultimately the content of its cartoons. He may even have taken a direct role in generating ideas for the journal's illustrations. His biographer surmises, though without evidence, that it was so; and his successor as functioning editor certainly played a large part in inventing the cartoons. ${ }^{19}$ O’Brien possessed a precise visual memory - as distinct, he claimed, 'as the outlines of a Flaxman drawing'. ${ }^{20}$ This quality may have carried over into inventing themes for the political imagery that was so important to the success of his newspaper. The endorsement of Gladstone shown in the cartoons from when he took up Home Rule may owe a great deal to O’Brien.

Although O'Brien remained editor of United Ireland after 1886, in that year he launched the Plan of Campaign that was designed to reignite the land agitation. By 
April 1887 his unguarded speeches had put him back behind prison bars. When leading the Plan of Campaign and even when in gaol, he was still in overall charge of his journal's policies, but the actual work of producing the newspaper passed into the hands of Matthias Bodkin as acting editor. Bodkin, a Roman Catholic lawyer from a Galway county family, had served with O'Brien on the Freeman's Journal and was recruited to write occasional editorials from the start of United Ireland. The acting editor was a resolute nationalist, but a moderate man, expecting the landlords to play a full part in a restored Irish parliament. His stock argument in favour of Home Rule was that it meant bringing about friendship between the two countries, Ireland and Britain. This stance was very like that of Bodkin's close friend Justin McCarthy: a firm commitment to Irish interests, support for a devolved parliament and reconciliation across the Irish Sea. ${ }^{21}$ Like McCarthy, who wrote a popular biography of Gladstone, Bodkin held the statesman in high regard. Although it was only after Bodkin had entered parliament for Roscommon in 1892 that he first set his eyes on Gladstone, the new MP had long been a devotee. He believed Gladstone's support for Home Rule was a genuine commitment to Ireland. In his memoirs, Bodkin waxes eloquent about many a 'matchless oration' of the 'miraculous old man'. ${ }^{22}$ His admiration undoubtedly impinged on the pictures in his newspaper. Bodkin tells us that while he served as acting editor, he 'suggested in detail the cartoon depicting the chief political event of the week' ${ }^{23}$ He imparted his own vivid sense of the power of scorn into the illustrations. Bodkin was in the Irish tradition of Jonathan Swift, believing in satire as a death-dealing weapon in public affairs. Especially in Ireland, he held, where the sense of humour was so strong, ridicule could kill. ${ }^{24}$ The lawyer ensured that the foes of Ireland did not escape unscathed. Consequently, while 
Gladstone was presented favourably, his opponents suffered from trenchant mockery in the cartoons published during Bodkin's period in charge.

Yet the men who actually designed the cartoons were artists. Chief among them was John D. Reigh, who signed nearly all of the illustrations in the bottom righthand corner. Very little is known of this man. He flourished from around 1875 to 1914, but we are not even aware of his second name. He was an accomplished painter, for he sold pictures at the Royal Hibernian Academy, Dublin, in the early 1880s. He contributed to United Ireland from early in O'Brien's editorship and he was also the favourite illustrator for the Shamrock, the nationalist monthly. According to Parnell, Reigh was 'the only one who can do justice to my handsome face'. ${ }^{25}$ Reigh naturally derived the subject of some of his graphics from high art, which he clearly saw as his province, but he also had a penchant for historical content. He portrayed, for example, several episodes from the 1798 rebellion, often depicting battle scenes. $^{26}$ Reigh was an ideal illustrator for a broad audience, combining bold images, popular themes and a clear message. In the new age of chromolithography, he delighted in using bright colour. Almost every week his creations appeared on a sheet enclosed with United Ireland, of the dimensions of a whole newspaper page, which was designed for posting, like a calendar, on the wall. Reigh was the man who, more than any other, constructed the Irish view of Gladstone in the years immediately after the proposal of Home Rule.

The cartoons that will be examined fall into three groups, relating respectively to the emergence of Home Rule in 1886, to the general election of that year and to the later 1880s. In the years before the first group, in 1884 and 1885, the cartoons 
consistently show Parnell as hero and Spencer, for so long as he remained Lord Lieutenant, as villain - a role for which, with his flowing red beard, he was well cast. Gladstone was a marginal figure, generally not treated as inveterately hostile but equally given no particular favour. On 6 February 1886, however, Gladstone comes forward into prominence in 'The Cabinet Trick' (Fig. 1). The whole illustration, showing a wooden cabinet, is an elaborate pun, for the Prime Minister had been forming the cabinet of his third administration during the previous week. On the very day the cartoon was published, the new ministers travelled to kiss hands at Osborne House. $^{27}$ The performance of the trick, according to the caption, was to take place at the Royal Theatre, St Stephen's, that is, at Westminster. The question was, 'How will he get out of it?' How, Reigh was asking, would Gladstone escape from the restrictions on his freedom? The statesman was known, since the flying of the Hawarden kite just before Christmas, to favour Home Rule, but would he be able to introduce so radical a departure in Irish policy? Gladstone appears benign and is treated sympathetically. He is bound by forces external to him, represented by the ropes labelled 'Anti-Irish Prejudice', 'Whig Mutiny', 'Integrity of Empire' (twice), 'Rack Rents' and 'No Popery'. At the top are the Protestant drum and the Catholic chapel bell, the religious components of the problem confronting the Prime Minister. With all these forces arrayed against him, he was like a stage artist about to attempt the apparently impossible. A measure of confidence in his abilities, however, is already in evidence. Gladstone is 'the renowned Wizard of the North', an allusion to his Midlothian constituency, and, after all, stage performers did succeed in disentangling themselves within closed cabinets. Clearly United Ireland is prepared to give Gladstone some credence: the long desired Home Rule might indeed come from his hands. 
The second cartoon, 'A Flag of Truce' (Fig. 2), appeared just over a month later, on 13 March. Drawing on the military imagery beloved by O'Brien and Reigh alike, it showed two armies drawn up for battle. On the left, Irish troops, marshalled under the banner of the harp, are commanded by Parnell. They face, on the right, British soldiers under the Union Flag. They are led by Gladstone, who, no doubt because he would appear wholly incongruous in military outfit, wears ordinary civilian clothes complete with a top hat. The prudent champions of the Irish cause have been told to ground arms, to wait and see what the Prime Minister was offering. O'Brien had heard from Parnell at a meeting in Morrison's Hotel in Dublin that Gladstone was indeed intending to proceed with a Home Rule measure. ${ }^{28}$ Accordingly the white flag of truce carried by Gladstone is inscribed 'Home Rule'. It also carries the legend 'Abolition of Landlordism', for the Prime Minister had indicated that the legislative programme would include drastic Irish land reform. The illustration still depicts Gladstone and Parnell as enemies, but there is nothing abject about the erect pose of the stalwart Prime Minister. The man, like his proposals, are appreciated as being worthy of respect.

Less than another month later, Gladstone has turned into a friend of the Irish people. In 'Taking the Landlords at their Word' (Fig. 3), issued on 3 April, Gladstone offers to put his projected land legislation into the fire. The intended massive compensation of $£ 120,000,000$ to landlords will perish with the plan. A representative Irish landlord, the booted figure at left centre, rejects Home Rule and land scheme alike. Colonel Edward Saunderson, leader of the Ulster Unionists, had threatened to bring over 10,000 northern English Protestants to fight for Ulster, ${ }^{29}$ and 
so in the cartoon the landlord is backed by 'Drummer Sanderson', crying 'Hooray! Death or glory! Blood and Civil War!' An unruffled Gladstone, however, outfaces his two opponents. The revolver falls from the landlord's hand as he blames Saunderson for losing him his compensation. The landlord and Saunderson are equally treated as figures of ridicule. A more sympathetic character, however, offers commentary on the scene. This is Pat, the cheerful young farmer who stood for Ireland in many a caricature of the period. ${ }^{30}$ From behind the table, Pat expresses in national brogue his satisfaction that Saunderson's alarmism has scotched the land bill because when the time comes for a settlement the landlord will be more 'raisonable'. Gladstone, unperturbed by the resistance of his opponents, is now master of events. His policy is shown as receiving the approval of Ireland even before he had put his proposals for Home Rule before parliament.

In the following week, on Thursday 8 April, Gladstone introduced his first Home Rule Bill. Two days later, on Saturday 10 April, United Ireland issued a portrait of the Prime Minister as its pictorial supplement. It was followed in successive weeks by four others: Henry Grattan, the leading orator in the last independent Irish parliament in the eighteenth century; Charles Stewart Parnell, the leader of the contemporary Irish national cause; and John Morley, the Chief Secretary for Ireland. Gladstone, together with his appointee, had entered the gallery of Irish heroes. Gladstone's portrait was a roaring success, making its edition of United Ireland the best selling issue ever. Over 125,000 copies were published, and production halted only because the litho machine broke down under the strain. ${ }^{31}$ In the following month, on 29 May, as though to confirm Gladstone's new-found status in Ireland, Reigh's cartoon depicted him, after Landseer, as 'The Grand Old Stag at 
Bay', standing on the Home Rule rock with hostile hounds baying all round. At that point the Home Rule Bill hung in the balance in the House of Commons, with Lord Hartington's Whigs and Joseph Chamberlain's radicals threatening to vote it down. By the time they did, on Tuesday 8 June, Gladstone had already been established as the central figure in Irish nationalist iconography.

On Thursday 10 June the dissolution of parliament was announced. During the subsequent election campaign, in the second group of cartoons for examination, United Ireland projected an image of Gladstone as the defender of the Irish people. On Saturday 12 June it offered its comment on the defeat of Home Rule in 'Arraigned!' (Fig. 4). A sour and crestfallen Chamberlain, easily identified by his trademark monocle, is presented as a prisoner at the dock charged with wilful murder of the bill. There was a prehistory here. Irishmen, according to Bodkin, found Chamberlain easy to dislike because of his 'alert self-assurance' and his 'caustic speech'. ${ }^{32}$ United Ireland had run a campaign against the Birmingham politician's visit to Ireland in 1885 and subsequent cartoons had portrayed him unflatteringly as an assassin (27 March 1886) and as an ass (5 June 1886). He had betrayed Ireland when, as radical leader, he might have been expected to endorse Home Rule. So on 12 June Chamberlain is shown as being haled into court before the august female figure of 'English Democracy', who grasps the sword of justice. Police Constable Gladstone guards the prisoner, holding a truncheon marked 'Democracy'. The odd symbolic tautology of democracy occurring twice in the same print is explained by its close association with both the politicians who appear. Chamberlain's earlier efforts, especially around the 1885 general election, to identify himself with the rising tide of democracy meant that he was justly answerable to its tribunal, but it is also clear that 
in Ireland Gladstone was perceived as its champion. By means of the 1884 Reform Bill, Gladstone's government had given the vote to roughly two-thirds of the male population. There had been a special impact on Ireland, where the level of the franchise had previously been set lower than in Britain. It was one of the act's achievements to standardise the qualification to vote throughout the United Kingdom, so enabling Parnell to sweep virtually all the southern Irish seats for nationalism at the 1885 general election. The democratic franchise that Gladstone had introduced, the cartoon implies, would bring Chamberlain to account at the new election that was just beginning. The charge against Chamberlain in the caption of the illustration is also revealing. The victim of the murder was 'a Treaty of Peace and Conciliation between the Irish and the English Peoples'. That was exactly the high view of the Home Rule Bill that Gladstone himself had envisaged. The measure was designed to establish a new and permanent relationship between the islands. So far as United Ireland was concerned, Gladstone's purpose had been fulfilled. As the policeman's uniform suggested, the statesman had become the agent of justice for Ireland. In the same issue, William O'Brien described Gladstone as 'a white old man with a face like a benediction and a voice like an Archangel's'. ${ }^{33}$ He had become a sublime figure in the nationalist pantheon.

As the general election gathered momentum, turning into a referendum on Home Rule, the cartoons unequivocally took Gladstone's side. On 3 July, the day after the first contested elections had taken place, United Ireland published 'Whose shall the Coffin be?' (Fig. 5) The coffin bears the inscription 'General Election 1886'. Drawing on a folk-tale, the message was that the combatants were entering on a 'death-struggle'. In the wake of the duel, one contender or the other would be 
consigned to the grave. On the left, defending the viewer, is Gladstone, wielding a sword which again is marked 'Democracy'. Rolling up his sleeves as though to chop down a tree, he wears no wing collar, for he is as ready for the fray as any ordinary worker. In Ireland, as in Britain, Gladstone had become 'the People's William'. On the far side of the coffin, in a loping pose, stands a three-headed monster marked 'Coalition'. The three heads are readily identifiable as (in the centre) Lord Salisbury, the leader of the Conservatives, and (on either side) Joseph Chamberlain and Lord Hartington, the dissident Liberals who had spurned Home Rule. The image stands in a long iconographic tradition of many-headed monsters, which in the eighteenth century had usually stood for arbitrary power. ${ }^{34}$ Similarly, in a previous picture, published on 8 May, Gladstone had been depicted as a mounted hero of ancient Greece attacking 'the Hydra-Headed Dragon of Prejudice, Bigotry and Treachery'. Now, however, the heads are personalised as the Unionist leaders, the three baleful opponents of the Liberal/Irish cause. Crucially, the monster's sword is marked 'The Classes'. The word reflects Gladstone's own rhetoric in which, in March of the same year, he had cast the struggle as one of the masses against the classes. ${ }^{35}$ The Liberal leader was now setting the terms of the commentary presented by the newspaper. He had captured the ascendancy in Irish political culture.

Two weeks later, on 17 July, the cartoon was entitled 'Well Done!' (Fig. 6). By this date, all the poll results except that for Orkney were in, and so the election was virtually over. ${ }^{36}$ This time the imagery is chivalric. Gladstone is a knight in armour, resting against a tree after combat. Once again, his sword is labelled 'Democracy', an indication of the strength of the association of the statesman with popular involvement in constitutional affairs. The dark maiden is Erin, wearing a 
green cloak, displaying a Tara brooch and holding her harp, a favourite representative figure for Ireland that Reigh used regularly. ${ }^{37}$ She proffers to Gladstone a glass of water to refresh him after his struggle. Below is a monster labelled 'Liberal Unionism', writhing in its death throes with a spear thrust through its head. This depiction represents no more than wishful thinking. As many as 78 Liberal Unionists had been returned to the new parliament, while the Gladstonian Liberals had been reduced to a rump of 191. The old serpent of Liberal Unionism was far from slain. In the eyes of United Ireland, however, it had been dealt a mortal wound by Gladstone's performance. The knight, Erin's champion in the lists, had won a moral victory. She offers him a symbol of her personal affection, for the cup is marked 'Love'. The word is perhaps appropriate to a scene governed by the conventions of courtly love, but it is a remarkably strong expression for the attitude of Ireland towards Gladstone. Here was a union of hearts indeed.

The third group of cartoons comes from the period in the later 1880s when Lord Salisbury headed a Conservative government that usually enjoyed the support of the Liberal Unionists. Its Irish policy, administered by the premier's nephew Arthur Balfour as Chief Secretary, pursued both conciliation and coercion, mingling small favours with resolute enforcement of public order. During this period the iconographic canons that had become established during the short time in 1886 when Home Rule was coming to the fore remained in full force. On 16 April 1887 in 'The Last of the Wolves', Reigh depicted Gladstone and Pat together resisting the wolf of coercion. Four months later, on 6 August 1887, in 'Thrown Over Board', a rackrenting Jonah is shown as tossed out of the Government Coercion boat by Salisbury and Hartington and pleading to be thrown a lifebelt marked 'Gladstone's Land Bill' 
from the Home Rule craft occupied by Gladstone and Parnell, again together. And in the following year, on 9 June 1888, a picture entitled 'The Key to the Position' illustrates John Bull, representing Great Britain, locked in fetters over the Irish difficulty. Various suggested solutions are on offer: Balfour carries the sledgehammer of coercion, Hartington wants to keep the fetters on and Chamberlain, the former metal manufacturer, holds a Birmingham file. Only Gladstone, however, holds the key, and that is Home Rule. The former Prime Minister, now leader of the opposition, is perceived as totally aligned with the Irish people in their quest for a devolved parliament.

In a print published on 29 December 1888, Gladstone's birthday, he receives something of an apotheosis in 'The Grand Old Man and his Calumniators' (Fig. 7). The anonymous design is not by Reigh and suffers from rather lifeless draughtsmanship, with too much blank space. Yet the purpose of glorifying Gladstone is self-evident. His statue holds an olive branch of peace in the right hand and a scroll of Home Rule in the left. On the plinth of the statue, the central figure of Britannia for England grasps the hands of Erin for Ireland and of another female figure for Scotland. The poetic inscription runs: 'A type that blends / Three steadfast friends / In love and peace for ever.' Gladstone, that is to say, has achieved permanent national reconciliation within the British Isles. Below to the right, a rabble led by Salisbury and Balfour cry 'Down with Gladstone' and are reduced to throwing stones. Irish folk apparently disport themselves to the left, but their significance is obscure, another sign of inferior craftsmanship. All the other figures, however, are dwarfed by the imposing statue of the Grand Old Man. The use of that title of affectionate respect, so common in Britain, is a further indication that Gladstone had 
earned a high place in the regard of nationalists. He is the Grand Old Man in Ireland too.

Six months later, on 22 June 1889, the picture supplement was of 'The Parting of the Ways' (Fig. 8). Britannia finds herself at a fork in the road, wondering which way to turn. She is poised, as the caption blatantly states the matter, 'between her good and evil geniuses'. On the left is a well groomed Gladstone, looking younger than his years, proffering an olive branch with ribbons marked 'Freedom' and 'Friendship'. On the right stands a portly Salisbury, appearing rather ridiculous in court dress, trying to jog Britannia's elbow to persuade her of the merits of manacles labelled 'Hatred' and 'Force'. One road is signposted 'Home Rule', the other 'Perpetual Coercion'. Britannia faces Gladstone and is inclined to take the olive branch, a visual prophecy that Britain will choose to support Home Rule at the next general election. Who is now the agent of Ireland's liberation? It is not an Irishman, for there is no trace of Parnell or even Pat upon the scene. It is Gladstone alone, embodying all that is good, who will bring about a favourable solution to the question of Ireland's future.

The cult of personality attained fresh heights six weeks later. On 3 August 1889 the United Ireland cartoon was entitled 'Gladstone's Golden Wedding' (Fig. 9). This illustration was remarkable because its theme was derived not from battle, folklore or whatever, but from Gladstone's private life. On 25 July the Liberal leader had celebrated the fiftieth anniversary of his wedding. The occasion was marked by the erection in Hawarden, Gladstone's home village near Chester, of an elaborate monument in the centre of the High Street and by an outpouring of popular 
enthusiasm in the opposition press for the event as a model for married folk. Reigh, however, treats the event as 'example and encouragement' in public affairs. Erin on the left, decked with flowers for her nuptials, steps forward shyly. On the right John Bull, sporting a rose in his buttonhole for his wedding day, offers his hand. The reconciliation between Ireland and Britain, it is implied once more, is to be founded on affection and so to be as permanent as Gladstone's marriage. The statesman himself is the central figure, bringing the two together. Perhaps there is an allusion to his celebrated piety, for he presides like a priest over the ceremony. In any case, the main thrust is spelt out: the picture commends 'The Union of Hearts'. Gladstone's own phrase has become Ireland's watchword. Clearly Gladstone the man as well as the statesman had come to dominate the Irish popular imagination.

Home Rule, of course, was not destined to come about. There was no Liberal landslide at the next general election, held in 1892, but rather a small majority of 40 for the Liberals and nationalists combined. It was possible, with difficulty, to press a Home Rule Bill through the Commons in 1893, but the Lords felt secure in dismissing it contemptuously. The chief explanation of the weakening of the Liberal/nationalist cause, by universal consent, was the scandal surrounding the O'Shea divorce case. When Parnell was pronounced guilty of adultery in a court of law, Gladstone declared that he could not continue to act with the nationalists so long as Parnell remained their leader. A majority of the Irish parliamentary party threw Parnell out, but a minority clung to him and he, with all his native obstinacy, insisted on remaining at their head. The breach was not healed by Parnell's death in 1891 but persisted, so that at the election of the following year the Irish were ruinously divided. In a sense, it was a polarisation between the two chief celebrities of the Home Rule campaign over the 
previous decade. Parnell, the earlier hero, naturally retained the loyalty of a significant number of supporters. But Gladstone, who had so evidently eclipsed Parnell in the graphics of United Ireland, was the choice of a larger proportion. He was supported by tacticians who calculated that Home Rule could come only through the Liberal alliance, but also by those who, mindful of the teaching of the Roman Catholic Church about personal morality, saw him as the embodiment of nobility in public life. That was possible because of Gladstone's projection as the champion of the Irish cause since 1886.

The Parnell spilt caused a revolution at United Ireland. Bodkin was initially puzzled about which side to take, but Gladstone's statement, followed by Justin McCarthy's election to the leadership of the parliamentary party in place of Parnell, convinced O'Brien that the newspaper should align with the anti-Parnellites. Accordingly on 6 December 1890 Bodkin's editorial declared against Parnell and the cartoon, not by Reigh, took the same line. Before the subsequent issue, however, Parnell seized the offices of the newspaper at night, dismissed Bodkin and destroyed most of the copies of the next edition. On 13 December United Ireland duly endorsed Parnell, publishing a cartoon by Reigh entitled 'Hail to the Chief!' that attempted to reinstate him in popular regard. ${ }^{38}$ Gladstone did not appear in the illustrations published at the time of the breach. Later on, however, as the newspaper persisted in its support for the Parnellites and came out in favour of outright independence, Gladstone is seen as trying to impose his will on Ireland. On 30 January 1892, for instance, Gladstone tells McCarthy, as leader of the anti-Parnellites, to take his medicine of a 'Subordinate Parliament' without opening his eyes. Reigh now depicts the Liberal leader as dictatorial and untrustworthy. The artist continued to serve the 
Parnellite cause in United Ireland down to its closure in 1898. In his eyes Gladstone was no longer a national hero but an alien politician playing fast and loose with Irish affairs.

For a while, however, from 1886 to 1890 , Gladstone was accorded a supreme place in Irish nationalist esteem. United Ireland, a journal with a record of extreme hostility to British rule, began to depict the statesman as the hope for Ireland's future. He was presented alongside Parnell, or more frequently by himself, as the champion of the nation. Gladstone's solution to the chronic problem of British misrule in Ireland seemed the right one: Home Rule. It was, after all, the remedy that the journal had long been advocating. When Gladstone proposed Home Rule in 1886, United Ireland quickly gave him its backing. The support of the newspaper ripened into adulation akin to what was felt among British Liberals. The cartoons illustrate this development vividly, bearing eloquent witness to the nature of mass Irish opinion. Ordinary Irish folk saw Gladstone as their spokesman, his enemies as theirs and his leadership of the Liberals as full of promise for their island. Because William O'Brien and Matthias Bodkin fell under his spell, and because John Reigh skilfully executed their wishes, Gladstone was able to forge a new sense of bonding between Ireland and Britain. Gladstone's commitment to Home Rule created a new political culture in Ireland. The cartoons of United Ireland show that he achieved his central aim in the later 1880s: a union of hearts.

\footnotetext{
${ }^{1}$ W. E. Gladstone, 'Place of Ancient Greece in the Providential Order' [1865], Gleanings of Past Years, 1843-79, 7 vols (London, 1879), Vol. 7, p. 63.

${ }^{2}$ L. Perry Curtis Jr, Apes and Angels: The Irishman in Victorian Caricature, rev. edn (Washington, 1997), pp. 68-72. Roy Douglas, Liam Harte and Jim O'Hara, Drawing Conclusions: A Cartoon History of Anglo-Irish Relations, 1798-1998 (Belfast, 1998), pp. 71, 88-9, 149.
} 
${ }^{3}$ Curtis, Apes and Angels, pp. 77-81. Douglas, Harte and O'Hara, Drawing Conclusions, pp. 3, 131, 137.

${ }^{4}$ S. J. Connolly (ed.), The Oxford Companion to Irish History (Oxford, 1998), p. 319.

${ }^{5}$ Ibid., p. 387.

${ }^{6}$ M. M'D. Bodkin, Recollections of an Irish Judge: Press, Bar and Parliament (London, 1914), p. 149.

${ }^{7}$ Sally Warwick-Heller, William O'Brien and the Irish Land War (Blackrock, 1990), p. 50.

${ }^{8}$ William O'Brien, Evening Memories (Dublin, 1920), p. 169.

${ }^{9}$ H. T. Dickinson, Caricature and the Constitution, 1760-1832 (Cambridge, 1986), p. 13.

${ }^{10}$ Warwick-Heller, O'Brien and the Irish Land War, pp. 53, 63.

${ }^{11}$ Philip Bull, Land, Politics and Nationalism: A Study of the Irish Land Question (Dublin, 1996), p. 103.

${ }^{12}$ United Ireland, 17 September 1881, quoted in Warwick-Heller, O'Brien and the Irish Land War, p. 54.

${ }^{13}$ William O’Brien, Recollections (London, 1905), pp. 493-6.

${ }^{14}$ C. C. O'Brien, Parnell and his Party, 1880-90 (Oxford, 1957), p. $81 \mathrm{n}$.

${ }^{15}$ Warwick-Heller, O'Brien and the Irish Land War, pp. 55, 71.

${ }^{16}$ United Ireland, 20 June 1885, quoted in ibid., p. 73.

${ }^{17}$ O'Brien, Recollections, p. 350.

${ }^{18}$ William O’Brien, Evening Memories (Dublin, 1920), p. 115.

${ }^{19}$ Warwick-Heller, O'Brien and the Irish Land War, p. 51. Bodkin, Recollections, p. 149.

${ }^{20}$ O'Brien, Evening Memories, p. 123.

${ }^{21}$ Bodkin, Recollections, pp. 147-8, 156, 231-2, chap. xxviii.

${ }^{22}$ Ibid., p. 205.

${ }^{23}$ Ibid., p. 149.

${ }^{24}$ Ibid., p. 168.

${ }^{25}$ F. S. L. Lyons, John Dillon: A Biography (London, 1968), opposite p. 133.

${ }^{26}$ L. W. McBride, 'Nationalist Constructions of the 1798 Rebellion: The Political Illustrations of J. D. Reigh', Eire- Ireland 34 (1999), pp. 120-1, 125, 129. Reigh's first name is given by Curtis, Apes and Angels, p. 69.

${ }^{27}$ A. B. Cooke and John Vincent, The Governing Passion: Cabinet Government and Party Politics in Britain, 1885-86 (Brighton, 1974), p. 368.

${ }^{28}$ O’Brien, Evening Memories, p. 101.

${ }^{29}$ Cooke and Vincent, Governing Passion, p. 105.

${ }^{30}$ Curtis, Apes and Angels, p. 75.

${ }^{31}$ O’Brien, Evening Memories, p. 169.

${ }^{32}$ Bodkin, Recollections, p. 235.

${ }^{33}$ O'Brien, Parnell and his Party, p. 193.

${ }^{34}$ Dickinson, Caricature and the Constitution, p. 21.

${ }^{35}$ Michael Barker, Gladstone and Radicalism: The Reconstruction of Liberal Policy in Britain, 1885 1894 (Hassocks, near Brighton, 1975), p. 90.

${ }^{36}$ Cooke and Vincent, Governing Passion, p. 438.

${ }^{37}$ Curtis, Apes and Angels, p. 75. McBride, 'Nationalist Constructions', p. 121.

${ }^{38}$ Bodkin, Recollections, pp. 172-5. Douglas, Harte and O’Hara, Drawing Conclusions, pp. 120-1. 